\title{
Manager perspectives on communication and public engagement in ecological restoration project success
}

\author{
Caroline Gottschalk Druschke ${ }^{1}$ and Kristen C. Hychka ${ }^{2}$
}

\begin{abstract}
We look to a particular social-ecological system, the restoration community in Rhode Island, USA and the rivers, wetlands, marshes, and estuaries they work to protect, to draw connections between communication, community involvement, and ecological restoration project success. Offering real-world examples drawn from interviews with 27 local, state, federal, and nonprofit restoration managers, we synthesize the mechanisms that managers found effective to argue that the communication employed by resource managers in each phase of the restoration process, in prioritization, implementation, and monitoring, and for garnering broad-based support, shapes the quality of public engagement in natural resources management, which, in turn, can impact the stakeholder, learning, and ecological success of restoration projects. Despite the possible trade-offs and conflicts between social and ecological outcomes, we suggest that managers need to consider their desired social-ecological outcomes and work from the outset to deliberately design mechanisms for communication and public engagement that weave community stakeholders into all phases of restoration projects in sustained and consequential ways.
\end{abstract}

Key Words: adaptive comanagement; adaptive management; communication; discourse analysis; natural resource management; public engagement; public participation; restoration; river; stakeholder engagement; water

\section{INTRODUCTION}

Not all public engagement is created equal. Studies have warned that stakeholder presence alone in natural resource decision making will not guarantee positive outcomes (Arnold et al. 2012, DeCaro and Stokes 2013). Still, based on the positive correlation Bernhardt et al. (2007) found between community involvement and ecological success, there is reason to believe that, done well, stakeholder involvement can support river restoration outcomes. However, little research explores how to cultivate the sorts of quality public engagement experiences that might contribute to restoration success. We take a transdisciplinary approach, suggesting that communication is key. We argue that the communication employed by resource managers in all phases of the restoration process shapes the quality of public engagement in natural resources management, which, in turn, can impact project success.

Palmer et al. (2005) distinguished between three axes for evaluating river restoration projects: ecological; learning; and stakeholder success. As they explained, "Stakeholder success reflects human satisfaction with restoration outcome, whereas learning success reflects advances in scientific knowledge and management practices that will benefit future restoration action" (Palmer et al. 2005:209). They emphasized that, "the most effective river restoration projects lie at the intersection of the three axes of success" (Palmer et al. 2005:209), but prioritized ecological success, which is characterized by five criteria: (1) guiding image of dynamic state; (2) ecosystems are improved; (3) resilience is increased; (4) no lasting harm; (5) ecological assessment is completed (Palmer et al. 2005). In a national survey of restoration managers, Bernhardt et al. (2007) linked ecological and stakeholder success, finding that the most ecologically successful projects, evaluated on three of the Palmer et al. (2005) criteria, were unique from others only in their employment of community involvement. However, the authors acknowledged, "our interviews did not allow us to understand how community involvement impacted the process" (Bernhardt et al. 2007:492).

This research extends Bernhardt et al. (2007) by considering the question of how: using managers' own words to highlight the powerful impact of communication and public engagement on multiple dimensions of success in aquatic restoration projects. Although Bernhardt et al. (2007) offered a wide, quantitative view of the connection between community involvement and project success, we take a deep, qualitative look at community involvement in one particular social-ecological system, the restoration community in Rhode Island, USA and the ecosystems they work to protect, in order to illuminate some of the on-theground connections between community involvement and project outcomes. We offer real-world examples where an emphasis on communication and public engagement in each phase of the restoration process, i.e., in prioritization, implementation, and monitoring, and for garnering broad-based support, improved the quality of stakeholder interactions, and also seemed to foster the types of learning and ecological successes that Palmer et al. (2005) defined.

Like Olsson et al. (2004) and others working in adaptive comanagement, which "links the learning function of adaptive management (experimental and experiential) and the linking (vertically and horizontally) function of comanagement" (Plummer et al. 2012), we endorse community-based systems of resource management, and argue that an increased emphasis on communication and public engagement can support the multidimensional success of river restoration projects. As Palmer et al. (2005:211) explained, "Restoration success should not be viewed as an all or nothing single endpoint, but rather as an adaptive process where iterative accomplishments along a predefined trajectory provide mileposts towards reaching broader ecological and societal objectives." Communication is a vital 
component of this adaptive process and should serve as an important management practice in the restoration toolkit. For restoration projects to achieve the widest suite of lasting successes, the restoration community needs to start talking about talking: sharing their successes and failures; highlighting their sophisticated sense of communication as something beyond oneway delivery of content; integrating communication goals and activities into adaptive management frameworks; and sustaining a community-wide discussion about listening, response, and engagement as supporting multiple aspects of project success. We hope to open that conversation here.

\section{LITERATURE REVIEW}

Our work extends a growing conversation in this journal and elsewhere about public participation in scientific research and environmental decision making. In an early review article, Stringer et al. (2006) explored the connection between participation and adaptive management in existing literature, urging a flexible and situated approach to public engagement. Subsequent work has been both celebratory (Barreteau et al. 2010) and critical (Turnhout et al. 2010, Arnold et al. 2012), with several articles providing conceptual frameworks for public participation in scientific research (Shirk et al. 2012) and institutional fit (DeCaro and Stokes 2013). Related work in adaptive comanagement explored similar territory, examining themes like public engagement, governance, and institutional capacity (Plummer et al. 2012, 2013, Smedstad and Gosnell 2013). These authors balance ethical and practical arguments to highlight the social aspects of social-ecological systems and explore the devolution of power from natural resource managers to invested public stakeholders.

Likewise, a handful of studies specific to restoration science and management has foregrounded the potentially useful consequences of engagement for restoration practice. Beyond Bernhardt et al. (2007) and their finding of the connection between community involvement and ecological success, Gross and Hoffmann-Reim (2005) contended that ecological restoration offers opportunities to involve the public in science, while Gobster and Hull (2000) focused on involving the public in setting ecological system-level targets for restoration. Meanwhile, Clewell and Aronson (2006) criticized the common technocratic approach to planning and implementation for precluding opportunities for public support of restoration.

Public participation has begun to receive increased attention in natural resources literature, with a variety of related papers addressing public participation efforts from the perspectives of stakeholders (Brewer 2011, Muro and Jeffrey 2012, DeCaro and Stokes 2013), policymakers (Huitema et al. 2010), and scientists (Davies 2008, Besley and Nisbet 2013). The field has also seen the introduction of useful and widely used typologies of public participation in scientific research (Shirk et al. 2012) and public engagement (Rowe and Frewer 2005). However, little if any research has explored manager-specific perspectives on public engagement. Meanwhile, mentions of communication in the restoration literature remain largely in the realm of content delivery, like Rowe and Frewer's (2005) category of "public communication" in which "information is conveyed from the sponsors of the initiative to the public" (254), and lack contextual perspectives of "deep communication" as an iterative, deliberative process that features sustained engagement and response (Gross 1994, Druschke 2014).

\section{METHODS}

Restoration managers are the glue that binds ecological, stakeholder, and learning successes. In the face of regulatory and financial constraints, managers negotiate on-the-ground decisions and serve as liaisons between ecological and social demands. With their technical and procedural experience and expertise, there is much to learn from managers' big picture perspective on the current state of restoration practice and the role of communication and public engagement in that process. We work here to highlight their voices.

Our study centers on the state of Rhode Island, the smallest (1212 square miles) but second most densely populated U.S. state. Its longest river is shorter than 50 miles, but the tiny state boasts 384 miles of tidal shoreline. Despite its size, there are a range of land uses and long, storied histories in most of its basins.

In summer 2013, we interviewed 27 local, state, federal, and nonprofit managers as part of a team from the U.S. Environmental Protection Agency's Atlantic Ecology Division developing an ecosystem services indicator approach for prioritizing freshwater wetland and buffer restorations. We investigated three research questions: (1) How do managers characterize their interactions with the public in restoration efforts? (2) How do managers approach public communication in different phases of the restoration process? (3) How do iterative communication processes between managers and stakeholders encourage self-reported success?

To recruit participants who would offer a wide variety of perspectives on aquatic restoration projects from a variety of institutional and geographic positions, we used a combination of heterogeneity and nonproportional quota sampling (Patton 2002, Oliver 2006, Lindlof and Taylor 2011). Heterogeneity sampling encourages the inclusion of a broad spectrum of views and opinions on an issue, while nonproportional sampling ensures that even small groups (defined, in our case, by institutional affiliation and freshwater/saltwater) are well-represented in the sample. Colleagues in the restoration community helped to identify an initial list of potential interviewees that included highprofile managers and organizational representatives, and we added names to the initial list through snowball sampling(Lindlof and Taylor 2011). We ranked potential interviewees from highest to lowest priority based on their prominence in restoration activity in Rhode Island and their ability to represent an otherwise untapped institutional or systemic view. We worked our way down that list, emailing multiple interview candidates in weekly clusters to schedule meetings, and stopped interviewing when we reached information saturation (Guest et al. 2006). We spread interviewees across institutional levels (municipal, state, federal, or nonprofit) and freshwater or saltwater restoration foci, and we talked with both men and women, who ranged in age from $\sim 35$ to $\sim 75$ years old (Table 1).

All but 2 of our 27 semistructured interviews were conducted faceto-face with participants. Interviews were 41 to 138 minutes long (mean of 79 minutes). We followed a predetermined interview script built from local knowledge and related research (Gobster 1998, Lindlof and Taylor 2011, Druschke 2013), but we welcomed 
participants to pursue paths of conversation that interested them. All interviews were audio recorded, and the audio recordings were sent to a transcription service for verbatim transcription. Returned transcripts were checked against the original audio recordings for quality assurance (average 99\% accuracy). Transcripts (2136 minutes; 750 pages) were imported into NVivo 10 software for coding and analysis.

Table 1. Characteristics of individuals in the restoration community interviewed for this study, including gender, freshwater and/or saltwater focus, and organizational affiliation.

\begin{tabular}{|c|c|c|c|c|c|c|c|c|}
\hline & \multicolumn{2}{|c|}{ Gender } & \multicolumn{2}{|c|}{$\begin{array}{c}\text { Ecosystem } \\
\text { Focus }\end{array}$} & \multicolumn{4}{|c|}{ Organizational Type } \\
\hline & Female & $\overline{\text { Male }}$ & $\begin{array}{l}\text { Fresh- } \\
\text { water }\end{array}$ & $\begin{array}{l}\text { Salt- } \\
\text { water }\end{array}$ & $\begin{array}{l}\text { Non- } \\
\text { profit }\end{array}$ & Local & State & $\overline{\text { Federal }}$ \\
\hline $\begin{array}{l}\text { Total } \\
\text { Managers }\end{array}$ & 11 & 16 & 23 & 13 & 10 & 4 & 6 & 7 \\
\hline
\end{tabular}

The authors took a content analysis approach (Montello and Sutton 2013) to the interview data, attending to the significant impacts of language and communication on natural resource management in participants' descriptions (Arnold et al. 2012, Jørgensen and Renöfält 2012). As Arnold et al. (2012) suggested, "Discourse is powerful; it is used to both understand and influence social-ecological systems." Therefore, with an eye to discourse and communication, and building in part from Gobster's (1998) work on public perceptions about the Chicago River, we developed an exhaustive code based on themes identified in the literature (deductive), as well as themes grounded in the transcripts (inductive). We met with our wider research team periodically, first to identify the most interesting and relevant themes emerging from initial transcripts and check the qualitative reliability of the coding scheme (Gibbs 2007), and later for peer debriefing to check the qualitative validity of our analysis (Creswell 2014). Although qualitative accounts are open to multiple plausible interpretations, to further validate our findings, we relied on triangulation (hearing similar accounts of the same restoration projects from multiple interviewees, as well as agreeing on interpretations between multiple researchers), considering negative case analysis (revising interpretations based on new evidence), and spending prolonged time in the field (conducting research over the course of a summer but continuing participant observation in the community over the course of multiple years; Lindlof and Taylor 2011, Creswell 2014).

The data that we include here was coded under the major heading "public engagement" and the subheading "models of public engagement," as well as the codes "prioritization," "implementation," "monitoring," and "broad based support for restoration." As we present passages from and analysis of those transcripts, for reasons of confidentiality in this small, highly networked state, we attribute all quotes to the generic term "Manager" followed by a sequential number referring to each individual. We employ the pronouns "she" and "her" for all interviewees.

\section{RESULTS AND DISCUSSION}

In the context of adaptive management, we asked interviewees to describe several restoration projects from inception to conclusion.
They offered many examples of innovative ways to collaborate with each other and with community members in the face of aquatic restoration challenges, and highlighted creative interactions with public stakeholders that were employed to achieve the sorts of stakeholder, learning, and ecological successes that Palmer et al. (2005) pointed to.

Conducting independent assessments of project success was not within the scope of this study, and we are well aware of the ongoing debate about what constitutes restoration success in the first place (Zedler 2007, Jähnig et al. 2011, Wortley et al. 2013, Nilsson et al. 2014). Despite the possible mismatch between measurable objectives and manager perceptions of success (Bernhardt et al. 2007), as well as managers' tendency to over-report success (Sabatier et al. 2005), we suggest there is value in listening closely to managers as they describe successes (and failures, the subject of a future paper), even if they may be overstated. Our sense is that a deep, rich look into managers' self-described work, especially as it relates to communication and community involvement, reveals important strategies and commonalities that can serve as a foundation for future study into clearer links between particular communication approaches and quantified stakeholder, learning, and ecological successes. Instead of evaluating projects as successful or unsuccessful based on managers' self-reported assessments or independent criteria, we looked to the specific details captured in their stories of success as illuminative foundations for future research, as well as instructive lessons for current restoration practice.

As restoration managers talked about their work, particular communication and engagement strategies that worked to support project success emerged from examples in four phases of the restoration process, including: prioritization; implementation; monitoring; and creating broad-based public support for restoration.

\section{Prioritization}

In the realm of prioritization, Manager 1 described a state initiative to involve members of the public in identifying buffer restoration sites in one urbanizing river basin. On this particular project, there was not enough funding to do site scoping, so the state organized a series of meetings to invite public input, assuming that recreational users of the river in question would be familiar with buffer areas in need of attention. She recounted:

People would go to different locations in the watershed, hold public meetings, pass out site nomination forms. [...] And we'd ask people if they knew of areas that [were degraded], and we got somethin' like 150, 160 [sites] from those workshop nomination forms. And then every one of 'em the consultant went out and visited and did an analysis on it. [...] So that nomination process counted for well over $90 \%$ of the projects that came outta that project, because what they realized was that the money that they had available to do the project wasn't enough to do the scientific recon for the level that needed to be done to get to the type and the number of projects that we wanted to get.

Manager 2 took an even more expansive approach to prioritization, starting not with nomination forms but with blank maps, and emphasizing the importance of inviting input from 
community members without making promises that might be difficult to keep. This, she explained, was key to establishing credibility. In her early days of working with what would later become a prominent watershed group in the state, Manager 2 spent a full year attending community meetings as an interested listener before presenting her project and engaging community members in the process of determining what might happen along the river corridor in question:

I saw how bureaucracies sort of imposed their way. And I decided to do the exact opposite. So we went into meetings with blank maps. We didn't go in with a plan. And we went in and we told them we don' thave anymoneycause we didn't-and we're not saying we're going to do anything for you. We're just saying we don't like the way this thing looks and if you could change it what would you do? And so I think we established a certain amount of credibility because we didn't go in promising something we couldn't deliver. We went in telling them we don't think we could deliver but, you know, if we could... what would happen?

Manager 3, the head of a major watershed organization, described a somewhat more hierarchical approach from Manager 2, but one that still positioned community members to play central roles in defining the group's agenda. Like Manager 2, Manager 3 thought that inviting input was important for the sake of directing their work, and that it also mattered for the group's ongoing reputation in the community to be seen as smartly spending money in a way that at least partially reflected the community's desires:

\begin{abstract}
As the official stewards of the watershed we kind of have to set the agenda. We are the experts and people look to us to be the experts 'cause we're the ones who are working on [the river]. But we wouldn't have known what to work on if we didn't ask, 'What's important? What's important to you?' We always still ask that question: 'What's important to you?' For example, we're tryin' to figure out what to do with a [particular] earmark. We have a lotta projects in mind. And we don't wanna do the wrong thing. [...] We don't want somebody to say to us, 'Hey you wasted all that money. You had this money and what did you do really?' We want them to say, 'Hey, thanks for listening to us. We're so glad that you chose that project. 'So we do have to go out and seek the right people's ideas and voices to help us steer our direction but if we don't have something to start with it's impossible.
\end{abstract}

As she later explained, those open lines of communication between the watershed group and the community at large played a role in their funding success, with funders looking for and rewarding these rich community connections. She described one stage of a river restoration project in the watershed as follows:

They did all these charrettes, these community charrettes, where they had planners and designers drawing what people were saying. Andmaking plans. And it's important to have that piece because then you can go to a funder and say, 'Look, here's a plan. This is how much it's gonna cost. This is the difference it's gonna make. And here's the people who it's gonna be affecting.' And we had all this input. You've got it documented 100 people want this and that's what makes a difference. [...] It does take that kinda legwork and partnership. And, you know, when you get that kinda groundswell, it's sort of unstoppable after that.

Managers 1, 2, and 3 pointed to these instances as smart strategies for getting restoration work done. They also pointed to them as restoration success stories that brought clear advances in both stakeholder and learning success where, "Stakeholder success reflects human satisfaction with restoration outcome" and "learning success reflects advances in scientific knowledge and management practices that will benefit future restoration action" (Palmer et al. 2005:209). These advances resulted from managers talking with and listening to the communities affected by their projects, approaching communication as a multidirectional act.

Although gains in ecological success, as Palmer et al. (2005) defined it, were less direct, these exercises did gather information that could contribute to both the guiding image of dynamic state and to preproject ecological assessment. In Manager 1's example, members of the public were able to identify sites that were good candidates for restoration, and, with the help of the consultant, that work was actually carried out on several sites, contributing to ecosystem improvement. In that case, in particular, public meetings had a positive impact because they were held early in the process and managers were open to citizen input guiding site selection. The move to rely on local knowledge, rather than a formal prioritization process, saved money that was then put directly into restoration, contributing to ecosystem improvement via stream buffers planted on an increased stretch of the river.

\section{Implementation}

Beyond prioritization, some interviewees focused on the necessity of engagement with the neighboring community to receive approval to implement projects on both private and public land. Many managers pointed to a particular dam removal in the state as one such example. In Manager 4's view, sustained presence was the key to success in that project:

You just have to be there. [...] In that case, for one thing, Manager 5 lives near there. So she knew a lot of people and she connected me with a lot of people. And then [...] Ijust got to know [a waitress] in the coffee shop and she was really into it. And she ended up doing a lot of outreach for us 'cause she knew everybody in town. [...] And we're still friends, you know? [...] You have to cultivate some people, like the guys who own [the local] garage. [...] And it's like right next to the dam. [...] We needed access through their property to do the project. I just started going there. [...] I'd just like go there and talk with [ the mechanic]. And he would be like under a car with his cigar like with a cutting torch cutting an exhaust system off or whatever. And he'd like roll out to say hi. And I just had to like go there, and you just have to sort of build credibility with people. And they ended up being awesome partners on the project.

Again, cultivating a relationship by opening a dialogue was key to building credibility, and that credibility was essential to implementation of this project and others. Thanks to the ongoing efforts of Manager 4 to communicate and cultivate a relationship with the garage owners, the owners ended up letting construction 
crews access the dam from their property. By all accounts, this dam removal would not have happened otherwise, and it prompted ecosystem improvement (i.e., allowing increased habitat connectivity for river herring, Alosa pseudoharengus and Alosa aestivalis, and American shad, Alosa sapidissima) and increased the resilience of the system (i.e., eliminating the need for dam maintenance), without causing lasting harm (i.e., preventing the release of contaminated sediment into the system). In that case, project managers have confirmed those impacts through extensive pre- and postproject ecological assessment.

Manager 6, likewise, pointed to the significant role of community members, and of restoration managers sustaining close relationships with community members, in making projects happen. As a representative of a strong and effective watershed group in the state, she has a wide-ranging role that she described this way:

Our role is not just to manage the money and to manage the projects, it's really to manage the local community and the cultural resources component, obviously in tandem with the lead federal agency and their Section 106 NEPA requirements. And it's hugely helpful. There isn't a day-especially when a project is on the ground-that the contractor doesn't have a local need, that the engineer doesn't have a local need, the funders don't have a local need, where you need that person that's in the community that knows the appropriate people to immediately go to to get an answer or to get assistance. [...] Quite frankly it helps to have that warm friendly known face, whether you're outreaching to the community or dealing with decision-makers. It's not somebody from another municipality or a state agency or a federal agency that's not familiar with the-for lack of a better term, flavor of the area-there's an automatic level of trust before the project even starts that's already been built for years between ourselves and the constituents, which is hugely helpful in getting these projects to go forward, not only more quickly and more efficiently but at a lot less expense than it might typically be done through a outside sponsor.

In interview after interview, managers pointed to the need to build trust through ongoing communication with community members; to keep them informed about projects and let them know about opportunities for involvement; to create opportunities for conversations early and often so that when crises arise, those sustained community relationships can ease and even enable project implementation.

\section{Monitoring}

In addition to prioritization and implementation, project successes resulted from public engagement in the critical but often neglected activity of monitoring. Just as Manager 1's example of soliciting recreational paddlers to identify potential buffer restorations emerged from a lack of funding, other managers described ways of engaging community members to get work done, such as project monitoring, that was typically cut from dwindling project budgets. Manager 6, for instance, described an elegant and cost-effective mechanism for including watershed residents in the process of monitoring and maintaining a buffer restoration:
As the invasives started to work their way closer to the water, it was just a simple matter of pullin' 'em out, which was way more effective than the other measures to keep out invasive species. So we ended up spendin' a total of $\$ 5,000$ instead of $\$ 72,000$ on stabilization, and created a great little kinda like landowner ownership. [...] We kinda educated [them] on what an invasive species is. [...] [And we said,] 'Even though the project's done, we're not done. We may need to come back. We want you to give us your input if you see problems occurring, as well as us doin' our own recon work.' So it's a great way to kinda like really wrap everybody's arms around the projects for that long-term ownership and buy-in.

In that case, Manager 6 had developed enough of a relationship with residents along the river in question that she had an intrigued if not willing audience. Community members were drawn in to the project because it tapped into their existing connections with the river, built an educational component onto their latent interests in the river's health, and empowered them to take responsibility for the project's success. Manager 7, involved in water quality monitoring efforts in the state, also spoke about the value of community-based monitoring but did so from a wider perspective:

\section{Typically with restoration projects there's not very often money to monitor afterwards. And so we don' tnecessarily know how successful a lot of these efforts are at least in terms of water quality. So having the volunteers out there can be really, really valuable and much more cost- effective way of seeing any benefit.}

Indeed, the community-based project that Manager 6 described was a cost-effective way of seeing benefit: contributing to ecosystem improvement, while providing input for postproject ecological assessment. Although the invasive management project benefited from community members' participation in monitoring and maintenance, this mechanism of engagement had the overarching benefit of cultivating what Manager 6 referred to as "long-term ownership and buy-in." Involving community members in the monitoring and maintenance of this buffer restoration made them more supportive of restoration projects in the watershed more generally, connecting metrics of stakeholder, learning, and ecological success. Manager 7 spoke in similar terms about her work, emphasizing the importance of involving people over time in protecting local water bodies while providing much needed input about restoration project impact.

\section{Broad-based support for restoration}

This broad-based support for ecological restoration efforts was referenced by a number of interviewees who pointed to sustained communication with community members as cultivating the sort of public buy-in that leads the community to provide support for restoration efforts in person, in their communities, and at their polling places. Although sustained and responsive communication with community members can take an incredible amount of work, done well, it can produce transformative effects for communities and their waterbodies.

This sort of sustained and responsive communication was central to the work of many managers with whom we spoke. Manager 4, in particular talked quite a bit about this perspective. She described it this way: 
Iprobably in a lot of cases do a lot more public interaction and stakeholder cultivation than some other people might because it's essential to not just being successful in the projects, but being successful in a way that people can buy into.

For Manager 4, the importance of long-term buy-in is an important management strategy, a key facet of adaptive management, and important to stakeholder, learning, and ecological success. Throughout our interviews, we heard managers refer to the importance of sustaining, and inviting community members to participate in, this ongoing conversation about ecological restoration, and we heard praise of managers who are especially talented in that regard.

Manager 8, for instance, a federal manager working primarily in coastal restoration, applauded the work of Manager 3, who works on freshwater issues at the other end of the state. In her discussion of her own efforts to involve children in educational activities that might attune them to ecosystem-based perspectives, Manager 8 applauded her colleague:

\begin{abstract}
Manager 3 has just done an amazing job of developing programs to get kids on the river, stewarding the river. I think that if you can give people a sense of ownershipand there's absolutely nothing better for somebody than to develop a sense of responsibility and ownership and pride around the whatever little bit of open space or wild areas or species that they have right in their backyard. Then that will transcend, you know, to everything else.
\end{abstract}

The sort of work that Manager 3 and many other managers accomplished in the realm of communication and public engagement was praised by a variety of interviewees as enabling positive changes for Rhode Island's rivers. Crucially, much of this work seems to happen on the local level, involving sustained faceto-face relationships between restoration managers and the communities with whom they engage.

One restoration manager and community activist, Manager 9, nicely summed up the impact of this sustained approach to communication on restoration success. Over a multiyear campaign, Manager 9 educated community schoolchildren about the degradation of a group of urban ponds and created signage about the public health hazards of subsistence fishing. That first year, after educating students and helping them create threedimensional signage and costumes, she led a group of more than 100 schoolchildren and community members on a procession through the watershed:

I remember [the head of the state agency that commissioned the signage] walking with me in the first procession. And he just said, almost shaking his head, he said, 'You know, you didn't give me what I asked for. You know, I wanted signs.' And by the first procession there were no signs. [...] I hadn't had time to [print the children's designs ] because I was all busy working with the kids doing the procession. So he said, 'You know, you didn't give me what I asked for, but you gave me what I wanted.'

She had not yet delivered informational signage, but she had cultivated a creative, iterative mechanism of public engagement that delivered a smashing success at the level of stakeholder involvement. And that sustained presence, by many accounts, has been even more effective than the actual signage now posted around the ponds. Although community residents visiting the urban ponds can read the new signage prohibiting fishing there, it seems plausible that community residents learn more about the health of the ponds, their history, and the possibility for water quality improvements through the annual procession. Indeed, every year since 2007, an ever-larger group of community members has marched through the watershed in celebration of the ponds, with a number of positive consequences.

At the level of stakeholder success, participants have come together as a community, have learned about water quality and restoration, and have educated others about those issues. At the level of learning success, managers have learned novel strategies for communicating about water quality and engaging community members in restoration efforts, while gathering local ecological knowledge about the ponds' health and historical ecosystem function. Also, at the level of ecological success, widespread interest in the procession may have influenced the state's decision to begin remediation of a former manufacturing facility at the water's edge, contributing to ecosystem improvement, increasing resilience, and bolstering a level of public scrutiny that forebodes well for ongoing ecological assessment. This procession and other iterative communication projects like it have the capacity to contribute to stakeholder, learning, and ecological successes, but only if public communication and engagement begin to play a more central, deliberate role in the adaptive management of our aquatic systems.

\section{The central role of communication in ecological restoration}

Consistently, the sorts of positive experiences with community engagement described by restoration managers involved what we refer to as an iterative form of communication that features sustained listening, response, and collaboration. Iterative communication involves repeating loops of information flowing between managers and stakeholders, a socio-ecosystem focus, sustained listening, and continual adaptive response.

When employing this model of communication, managers engaged with community members over time: listening and responding to their ongoing concerns and input; soliciting critical information to cocreate knowledge; and working collaboratively toward project goals. This iterative view of communication captures more than simply the direction of flow of information between scientists and members of the public (Rowe and Frewer 2005). We use the term iterative to label instances where managers use communication to build long-term, flexible, responsive relationships with community members that supported the prioritization, implementation, monitoring, and broad-based support of ecological restoration projects.

Managers who employed iterative models of communication worked creatively to involve members of the public in their projects, to consider how members of the public could support ecological outcomes, and to build trust over time. Through public meetings, charrettes, nomination forms, personal relationships, monitoring programs, art events, and more, they did this to great effect. 


\section{CONCLUSION}

It is clear from our interviews that many managers already employ creative approaches to communication in support of public engagement in ecological restoration projects, deliberately or otherwise. However, as our interviewees stressed, managers get few chances to reflect on the work they do and even fewer chances to share those reflections with the wider restoration community. We highlight managers' perspectives on communication and public engagement here because there is too little discussion about their role in the restoration process. We want to emphasize that the deliberate design of iterative communication mechanisms is a vital component of the adaptive management process and can contribute to wide-ranging positive outcomes in social-ecological systems.

We acknowledge the challenge of institutional constraints and the unpredictable nature of funding and collaboration, but managers can use the work presented here to design outcomedriven restoration projects that achieve ecological, stakeholder, and learning successes. We suggest they might do that by building from a modified version of Nyberg's (1999) framework for adaptive management. We propose that managers can embed a more deliberate perspective on public communication in the practice of adaptive comanagement by working through a process that includes the following: setting social-ecological outcomes; coprioritizing projects with stakeholders; codesigning both restoration projects and iterative engagement mechanisms; coimplementing; comonitoring; coevaluating ecological, stakeholder, and learning successes; communicating about successes and failures internally and externally; adjusting methods and priorities; assessing problems; and resetting social-ecological outcomes (Fig. 1). Despite the possible trade-offs and conflicts between social and ecological outcomes, we argue that managers need to consider their desired social-ecological outcomes and work from the outset to deliberately design mechanisms for communication and public engagement that weave community stakeholders into all phases of restoration projects in sustained and consequential ways.

Communication plays a central role in determining the quality of public engagement in natural resources management, which, in turn, can impact the success of restoration projects. We focused on restoration managers' experiences with community involvement in aquatic restoration projects to provide real-world examples of communication and public engagement in prioritization, implementation, monitoring, and broad-based support that improved the quality of stakeholder and learning interactions and prompted the sorts of ecological successes that Palmer et al. (2005) described. Critically, we argue that attention to communication is a key component of adaptive management and that iterative communication can foster stakeholder, learning, and ecological success.

However, this is just a first step. Future research can continue to focus on manager perspectives on communication and public engagement in ecological restoration practice, and attend to project failures as well as successes. We hope this research will also invite future explorations that fuse qualitative and quantitative methods to explore more concretely the connections between iterative communication and stakeholder, learning, and ecological successes.
Fig. 1. Framework for incorporating iterative public engagement into the adaptive comanagement of natural resources (adapted from Nyberg 1999). This ideal model can be used as a guiding framework, even if portions of the process may be difficult to adopt because of logistical, chronological, and financial constraints.

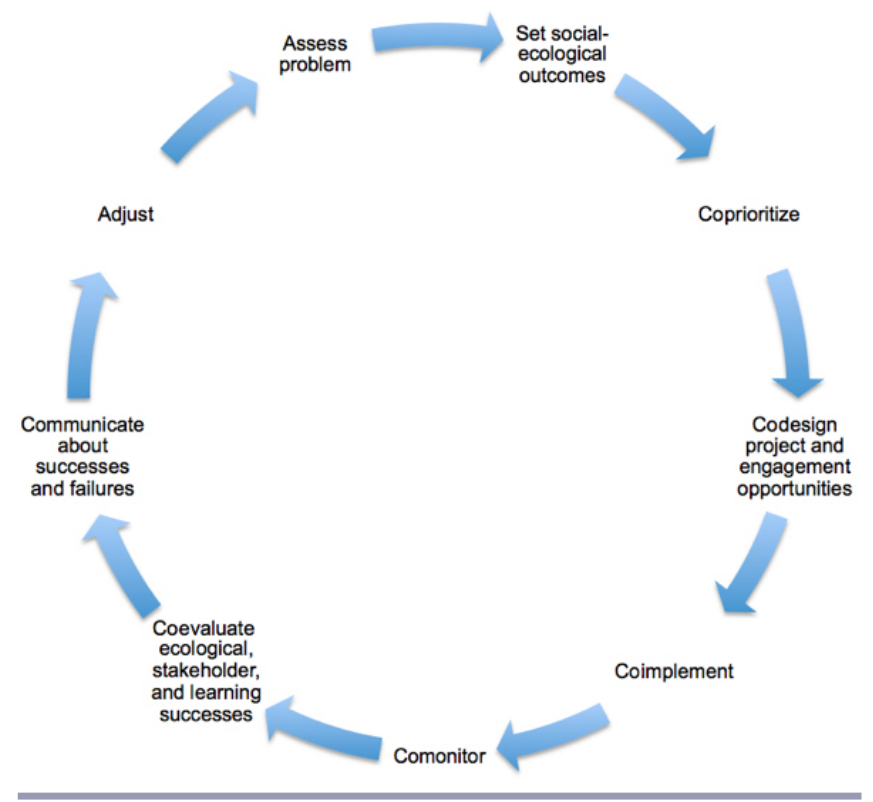

In the meantime, we encourage managers and the agencies they work with to practice adaptive comanagement by designing deliberately for communication-based public engagement with restoration; designing with desired outcomes in mind; and communicating about design and desired outcomes with affected publics. We hope that managers will include community members in all phases of the visioning, design, and implementation of restoration projects. Thoughtful and sustained public engagement can contribute to many of the criteria of stakeholder, learning, and ecological success proposed by Palmer et al. (2005). The richest and most illustrative stories that restoration managers shared with us described community members contributing to the achievement of those goals.

When members of the public are positioned to offer sustained support of restoration efforts, the restoration community will be able to achieve the lasting ecological, stakeholder, and learning successes upon which the fate of our aquatic ecosystems depends.

Responses to this article can be read online at: http://www.ecologyandsociety.org/issues/responses. php/7451

\section{Acknowledgments:}

First we thank our interviewees, whose experiences and efforts form the basis of this paper. We thank our anonymous reviewers and Walter Berry, Kate Mulvaney, Bryan Milstead, Jim Latimer, 
Marisa Mazzotta, Justin Bousquin, Claudette Ojo, Tim Gleason, and Wayne Munns for strengthening our manuscript through their generous feedback. This paper has not been subjected to US Environmental Protection Agency review. Therefore, it does not necessarily reflect the views of the Agency. Mention of trade names or commercial products does not constitute endorsement or recommendation for use. This contribution is identified by tracking number ORD-008938 of the Atlantic Ecology Division, Office of Research and Development, National Health and Environmental Effects Research Laboratory, US Environmental Protection Agency.

\section{LITERATURE CITED}

Arnold, J. S., M. Koro-Ljungberg, and W. L. Bartels. 2012. Power and conflict in adaptive management: analyzing the discourse of riparian management on public lands. Ecology and Society 17(1): 19. http://dx.doi.org/10.5751/ES-04636-170119

Barreteau, O., P. W. G. Bots, and K. A. Daniell. 2010. A framework for clarifying participation in participatory research to prevent its rejection for the wrong reasons. Ecology and Society 15(2): 1. [online] URL: http://www.ecologyandsociety.org/vol15/ iss $2 / \operatorname{art} 1 /$

Bernhardt, E. S., E. B. Sudduth, M. A. Palmer, J. D. Allan, J. L. Meyer, G. Alexander, J. Follastad-Shah, B. Hassett, R. Jenkinson, R. Lave, J. Rumps, and L. Pagano. 2007. Restoring rivers one reach at a time: results from a survey of U.S. river restoration practitioners. Restoration Ecology 15:482-493. http://dx.doi. org/10.1111/j.1526-100X.2007.00244.X

Besley, J. C., and M. Nisbet. 2013. How scientists view the public, the media and the political process. Public Understanding of Science 22(6):644-659. http://dx.doi.org/10.1177/0963662511418743

Brewer, J. F. 2011. Paper fish and policy conflict: catch shares and ecosystem-based management in Maine's groundfishery. Ecology and Society 16(1): 15. online [URL]: http://www.ecologyandsociety. org/vol16/iss1/art15/

Clewell, A. F., and J. Aronson. 2006. Motivations for the restoration of ecosystems. Conservation Biology 20:420-428. http://dx.doi.org/10.1111/j.1523-1739.2006.00340.x

Creswell, J. W. 2014. Research design: qualitative, quantitative, and mixed methods approaches. Sage, Thousand Oaks, California, USA.

Davies, S. R. 2008. Constructing communication: talking to scientists about talking to the public. Science Communication 29:413-434. http://dx.doi.org/10.1177/1075547008316222

DeCaro, D. A., and M. K. Stokes. 2013. Public participation and institutional fit: a social-psychological perspective. Ecology and Society 18(4): 40. http://dx.doi.org/10.5751/ES-05837-180440

Druschke, C. G. 2013. Watershed as common-place: communicating for conservation at the watershed scale. Environmental Communication: A Journal of Nature and Culture 7:80-96. http://dx.doi.org/10.1080/17524032.2012.749295

Druschke, C. G. 2014. With whom do we speak? Building transdisciplinary collaborations in rhetoric of science. Poroi 10 (1):10. http://dx.doi.org/10.13008/2151-2957.1175
Gibbs, G. R. 2007. Analyzing qualitative data. Sage, Thousand Oaks, California, USA.

Gobster, P. H. 1998. Nearby neighborhood residents' images and perceptions of the river. Pages 5-48 in P. H. Gobster and L. M. Westphal, editors. People and the river: perception and use of Chicago waterways for recreation. U.S. Department of Interior, National Park Service Rivers, Trails, and Conservation Assistance Program, Milwaukee, Wisconsin, USA. [online] URL: http:// www.nrs.fs.fed.us/pubs/misc/chicagoriver/peopleandtheriver.pdf

Gobster, P. H., and R. B. Hull. 2000. Restoring nature: perspectives from the social sciences and humanities. Island Press, Washington, D.C., USA.

Gross, A. G. 1994. The roles of rhetoric in the public understanding of science. Public Understanding of Science 3:3-23. http://dx.doi.org/10.1088/0963-6625/3/1/001

Gross, M., and H. Hoffmann-Riem. 2005. Ecological restoration as a real-world experiment: designing robust implementation strategies in an urban environment. Public Understanding of Science 14:269-284. http://dx.doi.org/10.1177/0963662505050791

Guest, G., A. Bunce, and L. Johnson. 2006. How many interviews are enough? An experiment with data saturation and variability. Field Methods 18(1):59-82. http://dx.doi.org/10.1177/1525822X05279903

Huitema, D., C. Cornelisse, and B. Ottow. 2010. Is the jury still out? Toward greater insight in policy learning in participatory decision processes - the case of Dutch citizens' juries on water management in the Rhine Basin. Ecology and Society 15(1): 16. [online] URL: http://www.ecologyandsociety.org/vol15/iss1/ $\underline{\operatorname{art} 16 /}$

Jähnig, S. C., A. W. Lorenz, D. Hering, C. Antons, A. Sundermann, E. Jedicke, and P. Haase. 2011. River restoration success: a question of perception. Ecological Applications 21 (6):2007-2015. http://dx.doi.org/10.1890/10-0618.1

Jørgensen, D., and B. M. Renöfält. 2012. Damned if you do, dammed if you don't: debates on dam removal in the Swedish media. Ecology and Society 18(1): 18. http://dx.doi.org/10.5751/ ES-05364-180118

Lindlof, T. R., and B. C. Taylor. 2011. Qualitative communication research methods. Third edition. Sage, Thousand Oaks, California, USA.

Montello, D. R., and P. Sutton. 2013. An introduction to scientific research methods in geography and environmental studies. Second edition. Sage, Thousand Oaks, California, USA.

Muro, M., and P. Jeffrey. 2012. Time to talk? How the structure of dialog processes shapes stakeholder learning in participatory water resources management. Ecology and Society 17(1): 3. http:// dx.doi.org/10.5751/ES-04476-170103

Nilsson, C., L. E. Polvi, J. Gardeström, E. M. Hasselquist, L. Lind, and J. M. Sarneel. 2014. Riparian and in-stream restoration of boreal streams and rivers: success or failure? Ecohydrology. http://dx.doi.org/10.1002/eco.1480

Nyberg, B. 1999. An introductory guide to adaptive management: for project leaders and participants. British Columbia Forest Service, Victoria, British Columbia, Canada. 
Oliver, P. 2006. Purposive sampling. Pages 244-245 in V. Jupp, editor. The Sage dictionary of social research methods. Sage, Thousand Oaks, California, USA.

Olsson, P., C. Folke, and F. Berkes. 2004. Adaptive comanagement for building resilience in social-ecological systems. Environmental Management 34:75-90. http://dx.doi.org/10.1007/s00267-003-0101-7

Palmer, M. A., E. S. Bernhardt, J. D. Allan, P. S. Lake, G. Alexander, S. Brooks, J. Carr, S. Clayton, C. N. Dahm, J. Follstad Shah, D. L. Galat, S. G. Loss, P. Goodwin, D. D. Hart, B. Hassett, R. Jenkinson, G. M. Kondolf, R. Lave, J. L. Meyer, T. K. O'Donnell, L. Pagano, and E. Sudduth. 2005. Standards for ecologically successful river restoration. Journal of Applied Ecology 42:208-217. http://dx.doi.org/10.1111/j.1365-2664.2005.01004. $\underline{\mathrm{x}}$

Patton, M. Q. 2002. Qualitative research and evaluation methods. Sage, Thousand Oaks, California, USA.

Plummer, R., D. R. Armitage, and R. C. De Loë. 2013. Adaptive comanagement and its relationship to environmental governance. Ecology and Society 18(1): 21. http://dx.doi.org/10.5751/ ES-05383-180121

Plummer, R., B. Crona, D. R. Armitage, P. Olsson, M. Tengö, and O. Yudina. 2012. Adaptive comanagement: a systematic review and analysis. Ecology and Society 17(3): 11. http://dx.doi. org/10.5751/ES-04952-170311

Rowe, G., and L. J. Frewer. 2005. A typology of public engagement mechanisms. Science, Technology \& Human Values 30:251-290. http://dx.doi.org/10.1177/0162243904271724

Sabatier, P. A., W. Focht, M. Lubell, Z. Trachtenberg, A. Vedlitz, and M. Matlock, editors. 2005. Swimming upstream. Collaborative approaches to watershed management. MIT Press, Cambridge, Massashusetts, USA.

Shirk, J. L., H. L. Ballard, C. C. Wilderman, T. Phillips, A. Wiggins, R. Jordan, E. McCallie, M. Minarchek, B. V. Lewenstein, M. E. Krasny, and R. Bonney. 2012. Public participation in scientific research: a framework for deliberate design. Ecology and Society 17(2): 29. http://dx.doi.org/10.5751/ ES-04705-170229

Smedstad, J. A., and H. Gosnell. 2013. Do adaptive comanagement processes lead to adaptive comanagement outcomes? A multicase study of long-term outcomes associated with the National Riparian Service Team's place-based riparian assistance. Ecology and Society 18(4): 8. http://dx.doi. org/10.5751/ES-05793-180408

Stringer, L. C., A. J. Dougill, E. Fraser, K. Hubacek, C. Prell, and M. S. Reed. 2006. Unpacking "participation" in the adaptive management of social-ecological systems: a critical review. Ecology and Society 11(2): 39. [online] URL: http://www. ecologyandsociety.org/vol11/iss2/art39/

Turnhout, E., S. Van Bommel, and N. Aarts. 2010. How participation creates citizens: participatory governance as performative practice. Ecology and Society 15(4): 26. [online] URL: http://www.ecologyandsociety.org/vol15/iss4/art26/
Wortley, L., J. M. Hero, and M. Howes. 2013. Evaluating ecological restoration success: a review of the literature. Restoration Ecology 21(5):537-543. http://dx.doi.org/10.1111/ rec. 12028

Zedler, J. B. 2007. Success: an unclear, subjective descriptor of restoration outcomes. Ecological Restoration 25(3):162-168. http://dx.doi.org/10.3368/er.25.3.162 